\title{
CORRECTION
}

\section{Correction: The therapeutic effect of ALT-711 on erectile function in rats treated with high-level AGEs (advanced glycation end products) containing diet}

N. Gurbuz (D), R. Gurkan, A. Ender Caylan, S. Surmen Usta and M. F. Usta (iD

๑) The Author(s), under exclusive licence to Springer Nature Limited part of Springer Nature 2022

IJIR: Your Sexual Medicine Journal (2022) 34:231; https://doi.org/10.1038/s41443-022-00544-w

Correction to: International Journal of Impotence Research https://doi. org/10.1038/s41443-021-00417-8, published online 12 March 2021
In this article, the author name A. Ender Caylan was incorrectly written as E. Ceylan. 